\title{
Big Ears - sonic art for public ears: Reflections on collaborative training
}

Franziska Schroeder, Queen's University Belfast

Koichi Samuels, Queen's University Belfast

Tullis Rennie, Queen's University Belfast

\section{Abstract}

This text critically reflects on the higher education public engagement training program, entitled 'Big Ears - sonic art for public ears'. The authors detail the objectives and aims as well as the benefits of this initiative for the enhancement of the student learning experience. We consider Schmidt's (Schmidt, 2012) notion of mis-listening and Christopher Small's concept of 'musicking' (Small, 1998), and develop a critical argument on how public engagement has changed researchers' views and attitudes about their own research. The text explores how the creative interaction with a young audience has had great impact on the students' learning experience as well as on their employability/transferable skills, because Big Ears stresses the importance of pulling practice as research away from the academic argument of why artists should be supported inside an institution, and into the realm of the real - what to do when making art, how to make it relevant and applicable to audiences.

Keywords: Education; sonic arts; public engagement; doctoral training

\section{Introduction}

This text is a collaborative work between three authors. Franziska Schroeder ${ }^{1}$ is the designer of the training program for public engagement entitled Big Ears - sonic art for public ears. Koichi Samuels and Tullis Rennie are two PhD students that took part in the program in 2013. Here, the authors explore aspects of the impact and learning experience for the $\mathrm{PhD}$ students involved in Big Ears, as well as the wider issues arising from such public engagement activities. All authors work at Queen's University Belfast's Sonic Arts Research Centre (SARC) - a unique interdisciplinary research facility, which brings together internationally recognised experts in the fields of musical composition, performance, signal processing and auditory perception. SARC's centrepiece is the purpose-built Sonic Lab, which provides a variable acoustic space for the creation and research of innovative compositional and performance work as well as for 3D sound diffusion research (SARC, 2013). It is therefore an ideal space for the exploration of sonic arts activities in the context of public engagement work.

\section{Big Ears: a public engagement training}

Public engagement describes the myriad of ways in which the activity and benefits of higher education and research can be shared with the public. Engagement is by definition a two-way 
process, involving interaction and listening, with the goal of generating mutual benefit (National Coordination Centre for Public Engagement - NCCPE, 2014 Capital Consultation)

Big Ears - sonic art for public ears is public engagement training for sonic arts and music researchers based at UK higher education institutions. It is, in accordance with the NCCPE's vision of public engagement, a two-way process between children and researchers. The training allows researchers to work in creative exchange with children aged $8-14$. It provides essential employability training including communication skills, project management, team-working, practical hands-on skills, an understanding of the relationships between practice and theory, and applied use of technology. Big Ears presents the opportunity to communicate creative practice as research to a wider audience, while highlighting the need for researchers to consider the public impact of their research. The NCCPE recently pointed to the absolute necessity for public engagement activities to have a capacity to build trust and to address public concerns about the future direction of research. Public engagement should enhance the quality of the research and should inspire future generations to pursue research careers; in short, it should improve the 'connectivity' of research with our wider society (NCCPE, 2014).

Having identified similar concerns about research and its potential for public engagement, Franziska Schroeder conceived the Big Ears training program in 2010. It was designed in collaboration with Young at Art (www.youngatart.co.uk) - a local arts organisation that run the annual Belfast Children's Festival. They contribute vital resources for the training program in bringing the course into the public arena; they support local symposium discussions, enable child protection procedures, obtaining parental permission and other consent forms, and they handle publicity and ticket sales under the umbrella of their annual festival (www.belfastchildrensfestival.com). Big Ears obtains ethical approval through the School's ethics committee and is recorded on the University's Human Subjects Projects Database for indemnity purposes. In that way, Big Ears is indirectly monitored by the Office for Research Ethics Committees in Northern Ireland, ORECNI (QUB Regulations, 2014).

The main aim of Big Ears is to provide innovative training in public engagement for researchers while creating essential links between the university and a local creative industry partner. The unique collaborative link between SARC and Young at Art allows UK sonic arts researchers to work alongside staff from the Belfast Children's Festival, to be creative together with local children whilst receiving support and guidance from experts in the fields of sonic arts and public engagement. Staff from SARC contributed expertise in the area of ubiquitous mobile and gaming technologies, sensor technologies, instrument design, composition and performance practice. In this way Big Ears acts as a way of publicly articulating the creative exchange between children in Northern Ireland and UK PhD sonic arts researchers.

Between 2011 and 2013, Big Ears has welcomed over 30 researchers from a large number of leading higher education UK institutions (Big Ears, 2011), and about 90 children have benefitted from the program. The children have been supported to explore ideas of listening, of interacting and experimenting with new technologies while being the driving force for the design of creative sonic art. Big Ears not only exposes children in Northern Ireland to trends in contemporary sonic arts research but importantly, it broadens the base of postgraduate students trained in working 
alongside children while allowing them to share and explore the impact their individual research could have with a wider public. Big Ears, in concordance with the vision of the NCCPE and the Concordat for Engaging the Public with Research, aims to demonstrate that research in sonic arts is relevant (tuned to societal needs and aspirations); that it is accountable (appropriately regulated to ensure value for money), and that it is trusted (aligned with society's values and ethical concerns) (NCCPE, 2014).

\section{Background Research}

During 2010, Franziska Schroeder carried out initial research towards the development and need for a specific public engagement training course. During that time a lack of essential employability and transferrable skills in the area of sonic arts research was identified. This shortcoming was recognised in light of the cessation of dedicated 'Roberts' funding but the continued importance of the 'Roberts' agenda (Hodsdon \& Buckley, 2011). Therefore, an increased demand for employability and personal development skills were highlighted to the Arts and Humanities Research Council (AHRC) in 2011 for one of their Collaborative Training Calls, and to the Higher Education Academy (HEA) in 2013. The HEA funded a revised version of the Big Ears training as an increased emphasis on researchers' transferrable skills, specifically the ability to communicate one's research, was deemed necessary. This meant that in 2013 the entire training course was designed, run and evaluated by $\mathrm{PhD}$ students.

Specific needs that were highlighted to the HEA in 2013 were as follows: Many postgraduates will not continue into academia. Nationally, $43 \%$ of PG students surveyed (Hodsdon \& Buckley, 2011) anticipated a career outside HE. It is thus important to provide opportunities to develop transferrable skills and to apply existing ones within new contexts. Results of Queen's University Belfast 2011 Postgraduate Research Experience Survey (PRES, 2011) showed that over $75 \%$ of students rate transferrable skills as important, and the 2012 national Postgraduate Taught Experience Survey (Bennett \& Turner, 2012) showed that 91.8\% had expectations met or exceeded for skills and personal development. Around four in five students agreed their programme had developed their research and transferable skills, which reflects the national picture. The Queen's survey identified an opportunity to investigate better ways of assisting students to further develop these skills. It also identified a lack of opportunities for social contact, and the 2013 Big Ears program aimed to address those issues.

The context in which people are doing research has changed to now include a greater emphasis on impact and public engagement. Big Ears, in addition to making outputs of the activities available, aims to provide a model for those both within the discipline and outside, as it supports the development of employability skills, relevant whether anticipating a career in academia or not. It also feeds into the national debate on further developing researchers' communication skills; a lack pointed to in the PRES (PRES, 2011), where only 66\% agreed that their programme had helped them present themselves with confidence or develop their communication skills.

Big Ears provides a platform for exchange between academic research and the public, and this core idea has been at the heart of the programme since its inception. A large part of the training is to enable $\mathrm{PhD}$ students to communicate their research objectives to a wider public - in the case 
of Big Ears this public consists of young children. Each year Big Ears culminates in a unique interaction showcase between the children and invited $\mathrm{PhD}$ students who collectively perform in a sonic mash-up that opens up ears and minds of all involved. The teams play with sounds, images and cutting-edge technological gadgets to produce ear-opening audio stories of gooey monsters, ghostly sea creatures and sonic dragons, staged at the unique performance space of the Sonic Lab at SARC.

\section{Collaborative Training, Collaborative Writing}

A large part of the Big Ears training focused on creative collaboration, and the three authors worked together exploring collaborative approaches during several training workshops. Therefore, it was a natural progression to explore and analyse the process of collaboratively writing about shared experience, which the authors elaborate here. The authors proceeded with a style of collaborative writing that Lowry et al. (2004) entitle 'mixed mode', since the authors commenced with a 'parallel writing style' strategy, where individual sections for the final text were identified and divided amongst the authors (horizontal division parallel writing). The authors then researched their topic and wrote parts of the text as three individuals. Ritchie et al. (2007) refer to this kind of writing as 'writing together metaphorically', where a physical sideby-side writing strategy is referred to as 'bodily co-present (or side-by-side) collaborative writing' (2007, p.3). The 'parallel writing style' strategy was followed by a 'reactive writing style' strategy when the three authors joined as a team to collaborate synchronously on the final text, in a side-by-side fashion. During this phase the text became adjusted according to the individual decisions that had been made during the 'parallel writing style' to produce a collaborative final piece.

It was a genuine concern for the authors to explore a collaborative writing approach, not only because historically academic institutions tend to be seen as rewarding individual work over team efforts and as rather lonely and isolated places for researchers and staff alike (Cronin, 2001); but also, the authors wanted to examine the assumption that the dialogical properties inherent in oral and written interactions between authors can offer transformative power in what Bakhtin refers to a 'culture-constitutive and self-reflexive process' (Bakhtin, 1981).

Collins (2004) had argued that 'writing side-by-side' establishes not only bodily presence but also shared emotional experiences, leading to the production of positive emotional energy or 'a feeling of confidence, elation, strength, enthusiasm, and initiative in taking action' (Collins, 2004, p.49). As the Big Ears training program provided many opportunities for participants to work side-by-side, providing a real sense of community and shared emotional experiences, the collaborative writing task was a further way of extending this communal collaboration while exploring collaborative research writing between the three authors. Kochan and Mullen have discussed collaborative writing and authorship in their work 'Collaborative authorship: reflections on a briar patch of twisted brambles' (Kochan \& Mullen, 2001, p.4), and Austin and Milem et al. have tackled the increasing interest in collaborative research writing since the beginning of the new millennium (Austin, 2001; Milem, et al., 2001). 
Through the Big Ears workshops and processes of collaboration in creating and performing a sound-based piece together, PhD students and the children gained specific skills and experiences that will be discussed in the following paragraphs.

\section{Mis-Listening and musicking}

In contrast to traditional musical forms of performance and composition, sonic arts and soundbased works enabled PhD students with expertise in this field of artistic practice to engage children to a high level of inclusion, enabling all participants to play an integral role in a performance piece. Sonic Arts has been identified as stylistically particularly conducive to enabling wide levels of participation because both audience expectations and composition and performance conventions are different from those framed within the standard Western classical system (Lyons, 2006). At the heart of Big Ears is the idea that creative engagement with different types of music and sound is encouraged; specifically it is of essence that children do not feel judged to be performing in the 'right' or 'wrong' way. As ethnomusicologist Thomas Turino (2008) argues, all forms of music fall into categories distinguished by different functions, values and levels of participation, and so one form of music cannot be judged in opposition to another form of music; experimental improvised music (or sonic arts) cannot be compared and judged along the same criteria as Western classical music. Moreover, because the functions, level of participation and levels of improvisation are different in different kinds of musics, judging nonWestern classical forms against the values and norms of the Western classical tradition ignores and undervalues the social and functional aspects of other forms of music.

Christopher Small's concept of 'musicking' (Small, 1998), explored in more detail below, is integral to the working of the Big Ears training. Small defined musicking as taking part in any capacity in a musical performance, arguing that music does not exist in the abstraction of notation, but always manifests in performance, in 'doing music', or 'musicking'. All participants in Big Ears are constantly and actively 'doing', working hands-on to create collaborative sonic arts.

Schmidt (2012) analyses music in terms of dialogue, which he asserts rather than the dialectic model where two or more views compete to be correct, is most useful when it takes the form of many views co-existing in a multiplicity of voices. Schmidt argues that dialogue is about showing difference. Similarly to the distinct voices in a dialogue, in music education pupils can learn from a plurality of different types of music. Perspectives from deconstruction theory and concepts of dialogue can be used to challenge traditional education and open up different kinds of music for study, which is explored in Big Ears, rather than solely the Western classical canon. Schmidt argues that including contemporary, experimental, and popular forms of music in lessons could allow a larger number of pupils to engage with music education.

Schmidt (2012) coins the term 'mis-listening' meaning to intentionally hear incorrectly or hear in a different way. Schmidt argues that if musicking differently could be described as doing music in a different way to the established and conformist way of creating music, mis-listening can be defined as listening to different musics and rejecting rigid ideas of what counts as music. He argues that opening up musical performance and composition to students without formal training 
enables them to gain confidence in altering or disrupting their own work in creative, improvisatory ways. The aims of musical engagement can thus be directed away from a concern with 'getting it right', which Schmidt argues is an over-concern with perfection and skill that has the effect of devaluing musical reflexivity and creativity in people who are not skilled musicians, towards experimentation and freedom of expression. Turino (2008) and Schmidt (2012) both lay the grounds for arguing that there are different values and functions for different types of music; the function of music doesn't have to solely revolve around creating perfect structures and compositions using music theory and conventions from the Western classical system, which, in the context of Big Ears, opened up the possibilities of a high level of engagement from all participants, regardless of musical background. Consequently, the final creations during Big Ears were envisaged as free from artistic or musical constraints and from many presumptions of what a musical/sound-based composition and performance should be.

\section{Participation and Performance}

Alongside encouraging 'mis-listening' and creative engagement with different types of sound and music are two other central themes underpinning Big Ears. These are participation in creative group work and performance.

Big Ears workshops aim to include and enable every $\mathrm{PhD}$ student and child to participate. Turino (2008), concerning the positive, personal well-being and psychic development-related benefits of participatory music cultures, cites Mihaly Csikszentmihalyi's research into 'flow' and the psychology of optimal experience. 'Flow states' are achieved in activities that comprise of the repetition of a pleasurable but still challenging task; for example sports, games, music and dance. Csikszentmihalyi (1990) argues that this is a heightened state of concentration where thoughts, concerns and distractions disappear and the actor is fully present. This open state of mind is integral to psychic growth and is liberating and relaxing to those acting in a flow state.

In more recent years, research by practitioners and sociologists into music therapy has shown that music can be appropriated in different ways and drawn upon as a resource to regulate emotions and influence personal well-being (DeNora, 1999, 2000, 2007). Research documenting Community Music Therapy practices as a contemporary area of music therapy, which focuses on group performances and musicking in communities as a social activity, has shown that music affords music therapy professionals a resource through which to include many participants in a unified activity, create a sense of individual and social identity and community, and enable participants to gain extra-musical skills through the process of socio-musical engagement (DeNora 2011; Stige et al., 2010).

The overall aim of participation in Big Ears workshops is to give an experience of performing using sound creatively and to collaboratively produce group performances, involving every child and $\mathrm{PhD}$ student. All creative outcomes are showcased in a final concert for the children's carers and members of the general public.

Ansdell (2010), in his ethnographic study on a community music therapy workshop and performance with instruments made from scrap metal, argues that music performance is closely 
linked with social emergence. Further, he references Sawyer's (Ansdell, 2010) sociocultural theory of group creativity based on his close study of improvising jazz musicians and actors suggesting that creativity is as much a socio-cultural process as a psychological one; group creativity is achieved through coordination, communication and collaboration. As a result, something new emerges from constant micro-communications that mediate cultural materials that the performers are working with and through. When viewed through the lens of the social sciences the non-aesthetic value of music becomes apparent. Performing and improvising is a challenging and valuable experience, especially in broadening the experience bases, character and abilities of children.

\section{Using Technology Together}

Participating children reported finding using recording technology and the Sonic Lab's audio mixing desk in the creation and performance of the sound-based works the most stimulating and enjoyable part of Big Ears $2013^{2}$. Research into computer-based play for engaging early years foundation children has shown that there are multiple benefits from engaging children with technology in a play-like or creative way, helping formal learning with computers become more natural and enabling children to be more confident in their engagement with them (Stancer, 2011).

Almost all of the PhD students that participated in Big Ears 2013 use computer technologies as an integral tool in their creative practices. Interviews showed that for them, working in the digital medium can be a lonely and isolating process, and the methods involved in $\mathrm{PhD}$ research are likewise solitary processes. Consequently, several $\mathrm{PhD}$ students reported that working with children and facilitating group work was a refreshing experience and provided an opportunity to step outside the studio to practically engage in discussion and teamwork, resulting in a new way of conceiving creativity through computer technologies. Rather than considering digital recording technology and sound equipment merely as tools or as static objects to be utilised, the Big Ears activities enabled both PhD students and children, through the specific affordances and particular capabilities of each piece of technology, to use the technology together as an activity rather than simply as an isolating object. Big Ears encouraged the use of computers and other audio technologies as process and activity and enabled participants to rethink their relationships to computers and digital technologies from a solitary, functional and alienating tool to a social, connective experience.

\section{Evaluation}

Since the start of the training course in 2011, Big Ears has been carefully monitored and evaluated by university staff, the local industry partner and by an independent ethnographer who provides in-depth evaluation and feedback reports. The ethnographer shadows the entire training over the course of four days. She interviews all the participants, including the participating children, PhD students and training staff in order to provide detailed feedback through video, audio recordings, through post-event questionnaires and children's drawings. The PhD students and all members of staff engage in a feedback session after the end of each Big Ears training 
event, which are detailed in the ethnographic reports. These reports are archived on the Big Ears website (Big Ears, 2013a).

The ethnographic reports consistently identified key elements of positive and effective practice. For example, creative control and autonomy, confidence building and team engagement as positive elements the children experienced. The reports further identified many key aspects that contributed to the PhD student's development, such as documenting how PhD students had assessed and perceived the impact that public engagement training may have on their research and practice.

The findings in the reports have lead to alterations in the training. In 2012 small changes, such as increasing the age of children from a minimum age of 7 to focus on slightly older children and changing the length and times of certain sessions, were implemented. Larger structural and organisational changes have resulted in Big Ears being entirely led and designed by $\mathrm{PhD}$ students (as pointed out above) in 2013. In response to critical feedback collected from $\mathrm{PhD}$ students suggesting that the programme should include a presentation highlighting the positive effects of participatory art/music projects for specific communities, roundtable debates with national speakers, addressing topics such as 'Sonic Art and Community Engagement' and 'Developing community', were implemented. $\mathrm{PhD}$ students in previous years had commented that they felt that this was a missing aspect to the programme. The organisers integrated it into the training by bringing in speakers with expertise in evaluating the effects of participatory art projects and community engagement work.

A greater concern elicited from some students was that they felt they would have benefited from more input on the application of the public engagement skills acquired during Big Ears. Students participating in 2013 responded that they would have liked to learn more about how to practically start a public engagement programme - about the actual steps from an idea to its implementation. In 2014, after the report found that researchers highly appreciate input from people working in industry, Big Ears was run by former BBC producer Gill Davies and Queen's University's Junior Academy of Music (JAM) co-ordinator Juliana Licinic.

\section{Trainee Reflection, 2013}

In 2013, the three days of collaborative Big Ears training for PhD students included workshops, discussions and presentations plus assistance in designing activities for the final day when over twenty children were present. Small collaborative groups of researchers were formed to plan and lead the day's activities for the creation and performance of sonic arts pieces.

During the Big Ears event, participating children were split into three groups, each led by a team of two to three PhD students and staff from Young at Art. All groups began with warm-up games, which involved creating sounds with the participants' bodies and acoustic props, exploring dynamics and expression in sound creation. The groups then worked on their specific projects. Group 1 (whose facilitators included authors Samuels and Rennie) created a 'sound safari', which involved hunting for sounds around the built environment of SARC. The team captured these new 'undiscovered' sounds with recording equipment and created a sound palette, 
which were consequently used to create a performance. Group 2 first invented a number of different short stories and then explored how they could tell them using a piano and all the different sounds that the instrument makes. Group 3 worked around the theme of 'What aNOISE me', looking for sounds that expressed annoyances in the children's lives.

The motivation and purpose of each of these works was not the creation of melody, musical form or harmonic structure, but rather starting from a concept or theme as a stimulus, explored through the creation, manipulation and performance of sound. The idea of mis-listening and creating different and unconventional musical or sound-based works with children is a central focus of Big Ears. As such, the sonic palette, and the way the sounds were combined and layered into a work for performance and how the sounds were actually performed, was decided and created by the group, enabling every single participant to be included regardless of musical skill or knowledge. Big Ears online documentation contains videos of the 2013 sonic outcomes (Big Ears, 2013b).

As well as experiencing an educational sonic arts activity, the children were actually participants in an ad-hoc study that aimed to answer a broader set of reflexive questions asked by the $\mathrm{PhD}$ students of themselves - namely: how can your academic research be applicable as a public engagement initiative, moreover to public engagement with 8 to 14 year-olds? What can the researcher gain from the experience of working with children?

Creative practice as research can at times lead to an (unintentional) emphasis on two elements that steer away from a focus on practising creatively, or making art. The first is the requirement for written argument and academic rigour in creative work. There is a constant pressure to convince a critical peer group that your work is new, original, and that it contributes to knowledge. A large body of writing on the question of PaR (practice as research), or PAR (performance as research) has been made over the years (see Suzanne Little, 2011 for an overview of this debate). The second is an over-reliance on the technological 'wow-factor'. This means the seduction of digital technologies and computer software performance can sometimes take precedence in creative work, which is not as artistically robust as it is technically innovative.

In undertaking the Big Ears public engagement training it became quickly apparent that when working with children, these two elements became much less important, if not almost completely irrelevant. The children were wholly unaware of the PhD students' backgrounds as researchers; to them they were simply adults who were facilitating a day of artistic workshops. There was no need to articulate or defend the reasons for recording, playing with and manipulating sounds. The value of composition at any age during education seems obvious: an emphasis on teamwork and collaboration and encouraging self-exploration and creative thinking are deemed positive attributes to a child's education - and it was not even a question for the children.

Secondly, children of ages 8-14 in the early 21 st century have a highly adept grasp of digital technology and computers. Digital technology is not a novelty for them - as it might be to those of a previous generation who have grown up through the age of rapid digital expansion - but a part of the fabric of their everyday life. While it was exciting for the children to have access to 
the inside of the Sonic Lab, to move sound around the space and manipulate it, it wasn't a concept that seemed strange to them. Moreover, the equipment and software to enable this seemed second nature - a living embodiment of Stancer's theories outlined above (Stancer, 2011). There was no technological barrier conceptually, and much less of a 'wow-factor'.

It wasn't only technology which seemed to be an 'adult' barrier that was easily surmounted (even dismissed) by the children taking part in the workshops. Conceptual and imaginative ideas on what obviously recognisable sounds could represent with a more abstract listening mind-set came easily and naturally - without the difficult of over-coming obvious 'source-bonding' (Smalley, 1994). Schmidt's concept of 'mis-listening' seemed to be inherent in many of the children, they had little or no value judgment on what should be deemed 'music' and were generally not concerned about 'getting it right'.

However, the act of focusing on sound only, sound without a visual source (played back through speakers) did become an issue in terms of attention - escaping the visually dominated world we inhabit and maintaining focus over a longer period on sound alone seemed much more of a challenge for the children. What did keep their attention was the chance to construct a fictional narrative story in sound, and translating this into a graphic score to guide the performance. The focus was on the storytelling, and the fact that it was told in an abstract form through spatialised and processed sound wasn't an issue for the participants. In fact, it was more a poignant thought for the researchers as the activity leaders, in identifying a need for them to re-imagine preconceptions about how children would receive and work with the idea of creatively devising and telling a story through abstract sound.

\section{Conclusions}

Feedback from both children and PhD students involved in Big Ears 2013 attests to the enriching and beneficial experience of creating sound-based works in groups together and performing these completed pieces to an audience. Children enjoyed and benefitted from the experience of being given the freedom and encouragement to be creative and engage in a new and exciting project. PhD students gained, among a host of skills and training, a broadened perspective on the kind of publicly focused work they could pursue in the future outside of the academic setting, as well as the possibility of working with children. Feedback showed that public engagement work with children helped the PhD students reflect on and discover new creative processes, the development of personal confidence, project management skills and the spontaneity required to work with children.

Big Ears activities enabled both PhD students and children to centre on the technology, using it as the focal point for activity and interaction, rather than simply as a functional object. This enabled participants to rethink their relationships to computers and digital technologies from a solitary, functional and alienating tool to a social, connective experience.

As Oliveros (2005), Lyons (2006), Turino (2008), Ansdell (2010) have underlined, the argument for the educational, social identity forming, and personal well-being related value of creative abstract composition, in this case through sound, is strong. The value of public engagement with 
children for researchers in higher education seems greater still. This value exists in pulling practice as research away from the academic argument of why artists should be supported inside an institution, into the realm of the real - what to do when making art, how to make it relevant and applicable to audiences. Being forced to play with ideas with a childlike attitude, to accept that many of the contextual elements to your academic arguments aren't quite as ground-breaking to a younger generation as you might hope, but are actually quite simple, should be taken as a reassurance. Rather than art as academia, it becomes art in and as part of education, and for researchers in higher education, that learning curve is without doubt a positive one.

\section{References}

Ansdell, G. (2010). Part VI. In Stige, B., Ansdell, G., Elefant, C. \& Pavlicevic, M. (eds) Where music helps: Community music therapy in action and reflection. Surrey: Ashgate Publishing Limited.

Austin, A. E. (2001) Reviewing the literature on scholarly collaboration: how we can understand collaboration among academic couples. In Creamer, E. G and Associates (eds) Working equal: Academic couples as collaborators. New York: Routledge Falmer.

Bakhtin, M. M. (1981) The dialogic imagination by M. M. Bakhtin: four essays. Austin, TX: University of Texas Press.

Bennett, P and Turner, G. (2012) The National Postgraduate Taught Experience Survey (PTES). Higher Education Academy. Available at https://www.heacademy.ac.uk/consultancyservices/surveys/ptes/ptes-final-reports (accessed 6/12/14).

Big Ears (2011) Big Ears site. Available at: http://www.socasites.qub.ac.uk/bigears (accessed 2/7/14).

Big Ears (2013a). Big Ears Ethnographic Report, 2013. Available at: http://www.socasites.qub.ac.uk/bigears/Documentation2013.html (accessed 2/7/14).

Big Ears (2013b). Big Ears 2013 site. Available at: www.socasites.qub.ac.uk/bigears/BigEars2013.html (accessed 2/7/14).

Collins, R. (2004) Interaction ritual chains. Princeton, NJ: Princeton University Press.

Cronin, B. (2001) 'Hyperauthorship: a postmodern perversion or evidence of a structural shift in scholarly communication practices?' Journal of the American Society for Information Science and Technology, 52 (7): 558-569. http://dx.doi.org/10.1002/asi.1097

Csikszentmihalyi, M. (1990). Flow: The Psychology of Optimal Performance. New York: Harper \& Row. 
DeNora, T. (1999) 'Music as a technology of the self'. Poetics, 27 (1): 31-56. http://dx.doi.org/10.1016/S0304-422X(99)00017-0

DeNora, T. (2000) Music in everyday life. Cambridge: Cambridge University Press. http://dx.doi.org/10.1017/CBO9780511489433

DeNora, T. (2007) 'Evidence and Effectiveness in Music Therapy: Problems, Possibilities and Performance in Health Contexts'. British Journal of Music Therapy, 20 (2): 81-99.

DeNora, T., (2011) Music-in-Action: Selected Essays in Sonic Ecology. Ashgate Publishing Company.

Hodsdon, L. and Buckley, A. (2011) Postgraduate Research Experience Survey 2011 results. Higher Education Academy. Available at:

https://www.heacademy.ac.uk/resources/detail/postgraduate/PRES_2011_report (accessed $6 / 12 / 14)$

Kochan, F. K. and Mullen, C. A. (2001) 'Collaborative authorship: reflections on a briar patch of twisted brambles'. Teachers College Record, February. Available at: http://www.tcrecord.org/content.asp?contentid=10661 (accessed 2/7/14).

Little, S. (2011) Practice and performance as research in the arts. In Bendrups, D. and Downes, G. (eds) Dunedin Soundings: Place and Performance. NZ: Otago University Press.

Lowry, P. B., Curtis, A. and Lowry, M. R. (2004) 'Building a taxonomy and nomenclature of collaborative writing to improve interdisciplinary research and practice'. International Journal of Business Communication 41 (1): 66-99. http://dx.doi.org/10.1177/0021943603259363

Lyons, F. (2006) Sonic Art - Opportunities for a Level Playing Field for Disabled Composers and Performers. International Journal of Technology, Knowledge and Society, 2 (2): 129-134.

Milem, J. F., Sherlin, J. H. and Irwin, L. E. (2001) The importance of collegial networks to college and university faculty. In Creamer, E. G and Associates (eds) Working equal: Academic couples as collaborators. New York: Routledge Falmer.

NCCPE. (2014) BIS consultation on proposals for long term investment in science and research. Available at: https://www.publicengagement.ac.uk/sites/default/files/publication/capital_consultation_briefing .pdf (accessed 4/7/14).

Oliveros, P. (2005) Deep Listening: A Composer's Sound Practice. Lincoln: Deep Listening Publications.

PRES. (2011) Queen's University Postgraduate Research Experience Survey, 2011 and 2012. Available at: 
http://www.qub.ac.uk/sites/PostgraduateCentre/PostgraduateCommunity/HaveYourSay/Postgrad uateExperienceSurveys (accessed 2/7/14).

QUB Regulations 2014 (2014) Regulations for Research Involving Human Participants. Available at: www.qub.ac.uk/directorates/ResearchEnterprise/ResearchGovernanceandEthics/FileStoreResGo v/Filetoupload,399949,en.doc (accessed 4/10/14).

Ritchie, S. M. And Rigano, D. L. (2007) 'Writing together metaphorically and bodily side-byside: an inquiry into collaborative academic writing'. Reflective Practice, 8 (1): 123-135. http://dx.doi.org/10.1080/14623940601139087

SARC. (2013) The Sonic Lab. Available at:

www.sarc.qub.ac.uk/sites/sarc/AboutUs/TheSARCBuildingandFacilities/TheSonicLab (accessed 2/7/14)

Schmidt, P. (2012) 'What We Hear is Meaning Too: Deconstruction, Dialogue, and Music'. Philosophy of Music Education Review, 20 (1): 3-24.

http://dx.doi.org/10.2979/philmusieducrevi.20.1.3

Smalley, D. (1994) Defining Timbre, Refining Timbre. Contemporary Music Review, 10 (2): 25 48. http://dx.doi.org/10.1080/07494469400640281

Small, C. (1998) Musicking: the meanings of performing and listening. Hanover: Wesleyan/University Press of New England.

Stancer, A. (2011) Engaging Early Years Foundation Stage children in computer-based play: a guide for practitioners. CfBT Education Trust.

Stige, B., Ansdell, G., Elefant, C. and Pavlicevic, M. (2010) Where music helps: Community music therapy in action and reflection. Surrey: Ashgate Publishing Limited.

Turino, T. (2008) Music as social life: Politics of participation. University of Chicago Press. 


\section{Notes}

${ }^{1}$ Franziska Schroeder is a public engagement ambassador for the NCCPE.

${ }^{2}$ Big Ears' technologies include software digital audio workstations; Max/MSP; Zoom H4 recorders; junk, card and paper, wood and metal; Sonic Lab (equipment microphones, digital effects rack, 48 channel mixing desk, 48 channel speaker system, projector/screen, lighting rig).

\section{About the authors}

Dr Franziska Schroeder is a saxophonist and theorist, a Lecturer at the School of Creative Arts and a Fellow of the HEA (Higher Education Academy in the UK). She serves on the peer review panel for the UK's AHRC (Arts and Humanities Research Council) and is a registered expert for the EU's Education, Audiovisual and Culture Executive Agency (EACEA).

Email: f.schroeder@qub.ac.uk

Koichi Samuels is a PhD student at the Sonic Arts Research Centre, Queen's University Belfast

Email: ksamuels01@qub.ac.uk

Tullis Rennie is a PhD student at the Sonic Arts Research Centre, Queen's University Belfast

Email: $\underline{\text { trennie01@qub.ac.uk }}$ 